\title{
ENDEMIC PEMPHIGUS FOLIACEUS (“FOGO SELVAGEM"): A SERIES FROM THE NORTHEASTERN REGION OF THE STATE OF SÃO PAULO, BRAZIL, 1973-1998
}

\author{
Maria Paula do Valle CHIOSSI(1) \& Ana Maria F. ROSELINO(1)
}

\begin{abstract}
SUMMARY
Endemic Pemphigus Foliaceus (EPF) is a bullous autoimmune skin disease whose incidence used to be high in the State of São Paulo (SP), Brazil, during the forties, but has declined thereafter.

Objectives: to report a series of EPF patients from the northeastern region of SP.

Methods: a retrospective study concerning demographic and epidemiological data of patients seen from 1973 to 1998 was conducted at the University Hospital, Faculty of Medicine of Ribeirão Preto, SP.

Results: bullous disease was diagnosed in 340 patients, 245 with EPF (72.1\%), 9.4 cases per year, $60.4 \%$ females, and $70.2 \%$ white, 7 to 82 year-old (29.4\% in their teens); $46.9 \%$ lived in the rural zone. Concerning profession, housewives predominated among women $(67.6 \%)$ and agricultural workers among men (40.2\%). The time of disease was less than 1 year in $62.0 \%$ of cases, followed by 1 and 5 years (27\%), and more than 5 years for the remaining patients $(11 \%) .36 .7 \%$ of patients were referred by the Direção Regional de Saúde (DIR) XVIII of Ribeirão Preto, with the largest number of cases being from Ribeirão Preto and Batatais: $33.3 \%$ and $23.3 \%$, respectively; 22\% from DIR XIII (Franca); $13.5 \%$ from DIR VII (Araraquara); $2.9 \%$ from DIR IX (Barretos); $4.1 \%$ from other DIRs of SP, and 20.8\% from other States (16.7\% from Minas Gerais). Thirteen (5.3\%) patients reported occurrence of the disease in some relative, and $4(1.6 \%)$ in neighbors.
\end{abstract}

Conclusions: the present data characterize the northeastern region of the state of São Paulo as a remaining endemic focus of EPF.

KEYWORDS: Pemphigus; Pemphigus foliaceus; Fogo selvagem; Epidemiology

\section{INTRODUCTION}

Endemic Pemphigus Foliaceus (EPF) or "Fogo Selvagem" (FS) is an autoimmune skin disease characterized by the presence of flacid bullae on the skin and absence of mucous lesions. Autoantibodies against the transmembrane glycoprotein of desmosomes named desmoglein 1 are present in the skin and serum of patients ${ }^{4,14}$.

EPF differs from the pemphigus foliaceus described by Cazenave in its endemic characteristics, including its geographical distribution and occurrence in young people ${ }^{2}$. More than 15,000 cases have been reported to occur in Brazil, most of them from the States of Goiás, Mato Grosso do Sul, Paraná, São Paulo and Minas Gerais. Cases have also been described in Paraguay, Argentina, Bolivia, Peru and Colombia ${ }^{5,16}$. The disease occurs in states located between $45^{\circ}$ and $60^{\circ}$ longitude west and $5^{\circ}$ and $25^{\circ}$ latitude south, altitude between 500 and $800 \mathrm{~m}$, with a subtropical climate 5 .

The first description of EPF in the State of São Paulo (SP) was made by Paes-Leme in 1903, using the wrong denomination of Tokelau ${ }^{16}$. In 1906, Luciano Gualberto described a focus of EPF in the city of Franca during the $7^{\text {th }}$ Brazilian Congress of Medicine and Surgery ${ }^{15}$. In 1942, VIEIRA reported the existence of EPF in the State of SP for more than 50 years in the case of a patient from Batatais who had acquired the disease more than 50 years ago and who remembered previous cases. We heard from elderly people who lived in Franca that their ancestors already knew the terrible "fogo selvagem"16.

During the thirties there was a marked increase in the number of cases in the State of São Paulo, which forced the government to create a Hospital only to treat EPF patients ${ }^{16}$. By 1946, 351 EPF patients had been treated at Pemphigus Hospital, where mortality was $40.7 \%{ }^{17}$.

In 1940, VIEIRA reported that two thirds of the State of SP was affected: northeast, northwest, west, and southwest, whereas the south and east regions and the littoral were not affected. In the northeast, the highest incidence of disease was in the Mogiana zone, from Franca to

(1) Division of Dermatology, Department of Medical Clinics, University of São Paulo, Faculty of Medicine of Ribeirão Preto, SP, Brazil

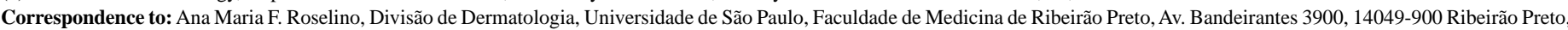
SP, Brasil. E-mail: amfrosel@fmrp.usp.br 
Ribeirão Preto, extending to the margins of the Grande River, including Ituverava and Igarapava. He pointed out that in Franca the Simulium fly (black fly, "borrachudo" in Portuguese) predominated in the areas most affected by EPF. In his study of 350 patients, he showed that the disease occurred predominantly among people aged 15 to 19 years and 25 to 29 years, among females and whites ${ }^{15}$.

In 1942, VIEIRA registered 460 cases and pointed out Franca and Ribeirão Preto as cities with the highest indices of the disease, besides the high incidence in almost all their neighboring towns. He described the maximum incidence of the disease among people aged 14 to 16 years and among whites (326 of 460 cases) and pointed out that the disease occurred preferentially among poor people from rural areas, and exceptionally in urban areas (Franca, São Carlos, Jaú and Bocaina) ${ }^{16}$.

In an epidemiological study conducted in 1973-74, PROENÇA reported 41 cases of EPF in the State of São Paulo, with a higher occurrence in women, in whites and in young people. He concluded that its occurrence was declining in the State of São Paulo, with the total disappearance of endemic foci ${ }^{9}$.

In 1988, CUNHA reported on 30 cases of EPF in the area of Franco da Rocha and Mairiporã (northwestern from the city of SP) studied from 1982 to 1987, and characterized the persistence of this old endemic focus considered as the last endemic focus of PF in the State of São Paulo ${ }^{3}$. In 1997, SARTORI BARRAVIERA \& DILLON studied 63 cases of EPF treated at the University Hospital of Botucatu, SP, from 1976 to 1993, with predominance of young, white, female, rural patients, besides occurrence in the same family. No endemic focus was detected ${ }^{13}$.

Thus, in the State of São Paulo, EPF has been observed since the beginning of this century, reaching a higher incidence in the thirties and forties $^{1,15-17}$, with a remarkable decline from the sixties to the eighties $\mathrm{s}^{3,9,13}$. The decreased frequency of EPF in the State of São Paulo may be related to advances in technology and to changes in ecology and in personal habits. Therefore, exposure to potential etiological factors, which could have precipitated EPF in the past but are no longer present, may have altered the epidemiology of the disease. In spite of the exponential population growth in the State in the last decades, the frequency of EPF declined remarkably ${ }^{5,10}$.
In view of the fact that the Ribeirão Preto region has been reported to be an important endemic focus of EPF since the forties, the objective of the present study was to report on a series of 245 cases of EPF in the northeastern region of São Paulo which occurred during the last 26 years.

\section{MATERIAL AND METHODS}

A retrospective study was conducted at the University Hospital, Faculty of Medicine of Ribeirão Preto, University of São Paulo (UHFMRP-USP), Brazil, on patients with a diagnosis of autoimmune bullous dermatosis, from 1973 to 1998 . Demographic and epidemiological data were recorded.

\section{RESULTS}

Over a period of 26 years, 340 patients with bullous autoimmune dermatosis were diagnosed. Among them, 245 (72.1\%) presented EPF, 9.4 new cases per year. In 1990, 23 new cases were seen (Fig. 1).

There was a predominance of women (60.4\%) over men (1.53:1). Age ranged from 7 to 82 years. Most cases (29.4\%) were patients in their twenties, followed by patients in their thirties $(20.0 \%)$ and forties (18.4\%), with $51.4 \%$ of cases being patients younger under 29 years, and $40.8 \%$ being 31 to 60 year-old. Only $7.8 \%$ of cases occurred in individuals older than 60 years.

Regarding race, $70.2 \%$ of patients were white, $20.4 \%$ mulatto and $9.0 \%$ black. Only one patient was Oriental $(0.4 \%)$.

Duration of EPF before treatment was less than one year in $62.0 \%$ of patients, 1 to 5 years in $26.9 \%$, and more than 5 years in $11.0 \%$. The predominant profession was housekeeping among women $(67.6 \%)$ and agricultural activities among men $(40.2 \%)$. 35\% of women were housekeepers in the rural area and $9.3 \%$ of agricultural workers lived in the urban area. $46.9 \%$ were originally from the rural area, $5.7 \%$ from the urban area, and in $47.3 \%$ of the cases this information was not available.

Patient origin was classified according to the "Divisões Regionais de Saúde" (DIR) of the State of São Paulo ${ }^{6}: 36.7 \%$ of the cases were



Fig. 1 - Annual distribution of 245 cases of EPF in terms of origin UH-FMRP-USP, 1973-1998. 
from DIR XVIII (Ribeirão Preto), 22.0\% from DIR XIII (Franca), 13.5\% from DIR VII (Araraquara), 8.9\% from DIR IX (Barretos), $4.1 \%$ from other DIR (São João da Boa Vista, Piracicaba, Bauru), and 20.8\% from other States, mainly Minas Gerais (Fig. 2).

It is interesting to point out the large number of cases from Batatais (33.3\%) and Ribeirão Preto (23.3\%) in the Ribeirão Preto DIR (Fig. 1 and 2). Thirteen patients (5.3\%) reported the occurrence of EPF in some relative, and $4(1.6 \%)$ reported this occurrence in some neighbor.

\section{DISCUSSION}

The Ribeirão Preto region, in the northeastern part of the State of São Paulo, corresponds to 2 Geographical Mesoregions, as defined by IBGE: Ribeirão Preto (microregions of Barretos, Batatais, Franca, Ituverava, Jaboticabal, Ribeirão Preto, São Joaquim da Barra) and Araraquara (microregions of Araraquara and São Carlos). The same region is divided into 4 DIRs (Ribeirão Preto, Franca, Araraquara and Barretos) $)^{6}$. It corresponds to 3.6 million hectares, approximately 2.5 million inhabitants and $14 \%$ of the territory of the State of São Paulo. The city of Ribeirão Preto is located at $23^{\circ} 10^{\prime} 42^{\prime \prime}$ latitude South and 47 $48^{\prime} 24^{\prime \prime}$ longitude West, at an altitude of $518 \mathrm{~m}$. The climate is tropical, with rainy summers and dry winters, and a mean temperature of $19^{\circ} \mathrm{C}$ in the winter and $25^{\circ} \mathrm{C}$ in the summer. Its hydrographic source is composed of the Mogi-Guaçu and Pardo Rivers (Instituto Geográfico e Cartográfico do Estado de São Paulo; Secretaria do Planejamento e Desenvolvimento).
The gross product of the region corresponds to US\$ 22 billion, US\$ 6 thousand per person. The region is the greatest producer of sugarcane, sugar and alcohol in Brazil and the greatest producer of food in the State of São Paulo (rice, corn, peanuts, beans, soybeans, oranges, lemons, guava, and mangoes). It is also the greatest producer and exporter of orange juice and the major producer of milk in São Paulo (Instituto Geográfico e Cartográfico do Estado de São Paulo; Secretaria do Planejamento e Desenvolvimento).

UH-FMRP-USP is a reference hospital for the northeastern region of the State of São Paulo and the south of Minas Gerais. A total of 25,690 new patients per year are seen, $46 \%$ from Ribeirão Preto, 24.4\% from other cities of the Ribeirão Preto DIR, $21.7 \%$ from other DIRs, and $7.7 \%$ from other States. A total of 429,003 outpatients are seen per year, 16,539 of them in Dermatology clinics (mean for the last 5 years).

Most of the EPF patients studied here over the 26 year period investigated were 11 to 19 years old, in agreement with the literature $\mathrm{e}^{5,12,15}$ and with the predominant age of the region population ${ }^{8}$. The majority of patients were women (1.53:1), as reported before ${ }^{1,9,13,15-17}$, although the values for Brazil as a whole do not show this difference ${ }^{7}$.

Regarding race, EPF predominated among white subjects. Only one Oriental patient was detected, as described previously ${ }^{11,13,15-17}$. This racial distribution could be explained by the racial distribution of the population in this region ${ }^{7}$, as suggested previously by PROENÇA ${ }^{9}$.

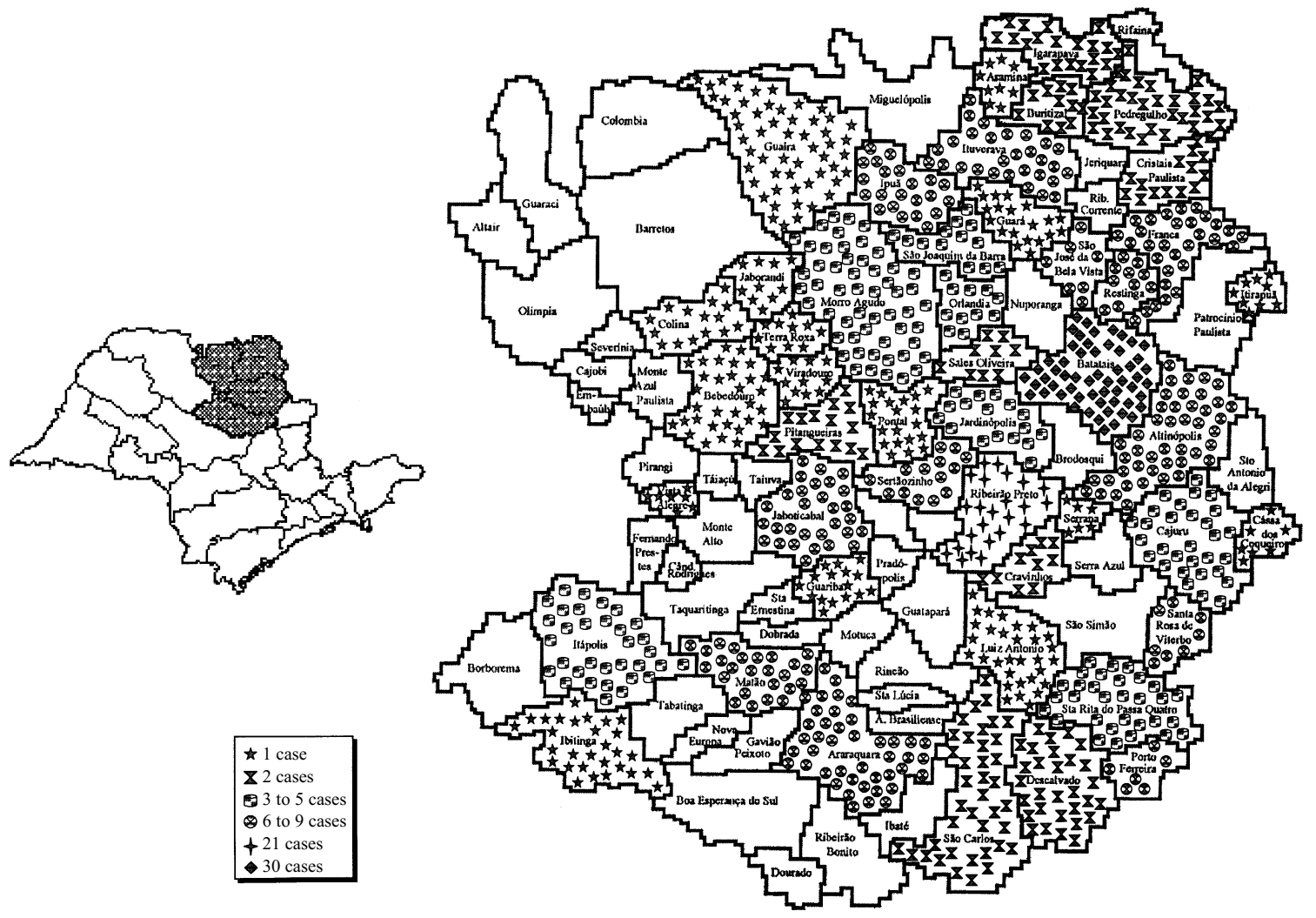

Fig. 2 - Distribution of 245 cases of EPF in terms of origin and town residence, UH-FMRP-USP, 1973-1998. 
The majority of patients were from rural areas, not only as residents, but also as rural migrant workers, as observed since the forties ${ }^{1,15,17}$, although $90.9 \%$ live in the urban area of the northeastern region of São Paulo.

In 1990, 23 new cases of EPF were from Ribeirão Preto and Batatais, coinciding with an outbreak of EPF detected at an Institution for abandoned children in the rural area of Batatais, from 1988 to $1990^{12}$. In 1990, the number of cases seen at UH-FMRP-USP and in Dermatology did not differ from the number seen in other years, a fact that does not explain the increased number of patients during this year.

Batatais has 47,996 inhabitants, with $6.9 \%$ of the population living in the rural area. The town has a high incidence of EPF, reaching 0.83 cases/ 10,000 inhabitants. Until 1987, only 2 cases were seen, with the number of cases increasing thereafter and continuing at this level until now ${ }^{12}$.

On the other hand, Ribeirão Preto had 79,783 inhabitants in 1940 and 456,252 inhabitants in 1996 (7 times higher) ${ }^{8}$, without a proportional increase in the number of EPF cases seen at UH-FMRP-USP. However, it should be remembered that there are many dermatologists in the Ribeirão Preto region who may see EPF patients in addition to those seen at UH -FMRP-USP, as observed by PROENÇA \& CASTRO $^{10}$. The highest incidence was in 1994, with 0.09 cases/10,000 inhabitants.

\section{CONCLUSION}

The present study agrees with the literature regarding age, gender, race, profession, and rural origin of EPF patients. It also characterizes the northeastern region of the State of São Paulo as a remaining endemic focus of EPF, with emphasis on the large number of cases from Batatais and Ribeirão Preto.

\section{RESUMO}

\section{Pênfigo foliáceo endêmico (Fogo Selvagem): casuística da região nordeste do Estado de São Paulo, Brasil, 1973-1998}

Fundamentos: $\mathrm{O}$ pênfigo foliáceo endêmico (PFE) é doença bolhosa auto-imune, em que o Estado de São Paulo (SP) destacou-se por sua alta incidência na década de 1940, a partir da qual é descrito seu declínio.

Objetivos: relatar casuística do PFE na região nordeste de SP.

Método: levantamento de prontuários de pacientes com doenças bolhosas, Hospital das Clínicas da Faculdade de Medicina de Ribeirão Preto, Universidade de São Paulo, 1973 a 1998, anotando-se aspectos demográficos e epidemiológicos.

Resultados: Do total de 340 pacientes com doença bolhosa, em 245 foi diagnosticado PFE (72,1\%), 9,4 casos/ano. Desses, 60,4\% eram mulheres e 70,2\%, brancos, de 7 a 82 anos de idade (29,4\% entre 10 e 19 anos); 46,9\% eram de zona rural. Predominou a profissão doméstica entre as mulheres $(67,6 \%)$, e lavrador entre os homens $(40,2 \%)$. Em $62,0 \%$, a duração da doença foi menor que 1 ano; em 27,0\%, entre 1 e 5 anos, e, em $11,0 \%$, maior que 5 anos. 36,7\% eram procedentes da Direção Regional de Saúde (DIR) XVIII de Ribeirão Preto, sendo que os municípios de Batatais e de Ribeirão Preto apresentaram maior número de casos: 33,3\% e 23,3\%, respectivamente; $22,0 \%$ da DIR XIII (Franca); $13,5 \%$ da DIR VII (Araraquara); $2,9 \%$ da DIR IX (Barretos); 4,1\% de outras DIRs de SP, e $20,8 \%$ de outros Estados (16,7\% de MG). Treze $(5,3 \%)$ pacientes relataram PFE em algum familiar, e $4(1,6 \%)$, em vizinhos.

Conclusões: Os dados confirmam a região nordeste de SP como foco endêmico remanescente de PFE.

\section{ACKNOWLEDGEMENTS}

The authors are thankful to the Dermatology staff of UH-FMRPUSP, and specially to Dr. Ana Márcia de Almeida.

\section{REFERENCES}

1. ARANHA-CAMPOS, J. - Pênfigo foliáceo (fogo selvagem). Aspectos clínicos e epidemiológicos. São Paulo, Melhoramentos, 1942.

2. CASTRO, R.M. \& PROENÇA, N.G. - Semelhanças e diferenças entre o fogo selvagem e o pênfigo foliáceo de Cazenave. An. bras. Derm., 58: 137-139, 1983.

3. CUNHA, P.R. - Estudo soro-epidemiológico em foco de pênfigo foliáceo endêmico (fogo selvagem) no estado de São Paulo. São Paulo, 1988. (Tese de Doutorado Faculdade de Medicina da Universidade de São Paulo).

4. DIAZ, L.A.; SAMPAIO, S.A.P.; RIVITTI, E.A. et al. - Endemic pemphigus foliaceus (Fogo selvagem). I. Clinical features and immunopathology. J. Amer. Acad. Derm., 20: $657-659,1989$.

5. DIAZ, L.A.; SAMPAIO, S.A.P.; RIVITTI, E.A. et al. - Endemic pemphigus foliaceus (Fogo selvagem). II. Current and historic epidemiologic studies. J. invest. Derm., 92: 4-12, 1989.

6. GOVERNO DO ESTADO DE SÃO PAULO. SECRETARIA DE ESTADO DA SAÚDE - Decreto 40.083 de 15/05/95. Diário Oficial do Estado de São Paulo, 105(91): 5 6, 1995. Seção I.

7. INSTITUTO BRASILEIRO DE GEOGRAFIA E ESTATÍSTICA (IBGE) - Censo Demográfico, 1991. (www.ibge.gov.br).

8. INSTITUTO BRASILEIRO DE GEOGRAFIA E ESTATÍSTICA (IBGE) - Contagem de População, 1996. (www.ibge.gov.br).

9. PROENÇA, N.G. - Declínio do pênfigo foliáceo no estado de São Paulo (Brasil). Rev paul. Med., 89: 97-100, 1977.

10. PROENÇA, N. \& CASTRO, R.M. - Geografia médica do pênfigo foliáceo sul-americano. An. bras. Derm., 46: 253-260, 1971.

11. PROENÇA, N.G. \& RIBEIRO, A.G. - Aspectos epidemiológicos do pênfigo foliáceo no Brasil. Resultados preliminares. Rev. Ass. méd. bras., 22: 281-284, 1976.

12. ROSELINO, A.M.F. \& ALMEIDA, A.M. - Surto de pênfigo foliáceo endêmico em instituição para menores em Batatais, Estado de São Paulo, Brasil, 1988-1990. Medicina (Ribeirão Preto), 28: 44-50, 1995

13. SARTORI-BARRAVIERA, S.R.C. \& DILLON, N.L. - Pênfigo foliáceo no Hospital das Clínicas da Faculdade de Medicina de Botucatu, SP. An. bras. Derm., 72: 533-537, 1997.

14. STANLEY, J.R.; KLAUS-KOVTUN, V. \& SAMPAIO, S.A.P. - Antigenic specificity of fogo selvagem autoantibodies is similar to North American pemphigus and distinct from pemphigus vulgaris autoantibodies. J. invest. Derm., 87: 197-201, 1986.

15. VIEIRA, J.P. - Novas contribuições ao estudo do pênfigo foliáceo (fogo selvagem) no Estado de São Paulo. São Paulo, Empresa Gráfica da Revista dos Tribunais, 1940.

16. VIEIRA, J.P. - Pênfigo foliáceo e síndrome de Senear-Uscher. São Paulo, Empresa Gráfica da Revista dos Tribunais, 1942

17. VIEIRA, J.P. Considerações sobre o pênfigo foliáceo no Brasil. São Paulo, Empresa Gráfica da Revista dos Tribunais, 1948.

Received: 27 July 2000

Accepted: 6 November 2000 